\title{
DETERMINAN STRUKTUR MODAL EMITEN \\ ANGGOTA DAFTAR EFEK SYARIAH
}

\author{
Oleh: Rizal Ma`ruf Amidy Siregar \\ Dosen Fakultas Ekonomi dan Bisnis Islam IAIN Padangsidimpuan \\ e-mail: amidy.siregar@gmail.com
}

\begin{abstract}
This study was tried to see the effect of the fundamental financial ratios as internal factors and sharia stock prices as an external factor on the characteristics of the capital structure. Emiten in this research are companies that is always listed in the Jakarta Islamic Index from 2012 through 2014. There are eighteen companies that qualify for the study limitation. The researcher found that the structure of assets (Model 1 and Model 3) and the sharia stock price (Model 2 and Model 3) is always have a negative effect on the capital structure. Thus, the increase in asset structure and sharia stock prices led to a decrease in capital structure, and vice versa. In other words, increasing in those two variables have a stake in the management decision to reduce the proportion of long-term debt, and vice versa. One variable that is always has positive effect is the sales growth.
\end{abstract}

Keywords: Capital Structure, Fundamental, Sharia Stock Price

\section{A. Pendahuluan}

Daftar Efek Syariah (DES) adalah kumpulan Efek yang tidak bertentangan dengan Prinsip-prinsip Syariah di Pasar Modal, yang ditetapkan oleh Badan Pengawas Pasar Modal dan Lembaga Keuangan (Bapepam-LK) atau pihak yang disetujui oleh Bapepam-LK. ${ }^{1}$ DES tersebut merupakan panduan investasi bagi Reksa Dana Syariah dalam menempatkan dana kelolaannya serta juga dapat dipergunakan oleh investor yang mempunyai keinginan untuk berinvestasi pada portofolio Efek Syariah.

Penetapan saham emiten yang memenuhi kriteria efek syariah adalah berdasarkan laporan keuangan berkala yang disampaikan oleh setiap emiten kepada Bapepam-LK setelah Surat Keputusan DES secara periodik ditetapkan. Suatu saham dikategorikan sebagai saham syariah apabila memenuhi rasio-rasio keuangan sebagai berikut ${ }^{2}$ :

- total utang yang berbasis bunga dibandingkan dengan total asset tidak lebih dari 45\% (empat puluh lima persen); 
- total pendapatan bunga dan pendapatan tidak halal lainnya dibandingkan dengan total pendapatan usaha (revenue) dan pendapatan lain-lain tidak lebih dari $10 \%$ (sepuluh persen).

Apabila persyaratan di atas terpenuhi dan sesuai prinsip syariah ajaran Islam yang penetapannya dilakukan oleh DSN-MUI, ${ }^{3}$ maka saham emiten atau perusahaan publik tersebut lolos sebagai kategori saham syariah dan akan dicatat dalam Daftar Efek Syariah.

Data Bapepam-LK (yang kemudian bertransformasi menjadi Otoritas Jasa Keuangan - OJK pada tahun 2013) dari tahun 2007-2012 menunjukkan bahwa pertumbuhan saham emiten yang memenuhi syarat sebagai saham syariah terus meningkat. Data perkembangan saham syariah tahun 2007-2012 selengkapnya dapat dilihat pada Gambar 1.

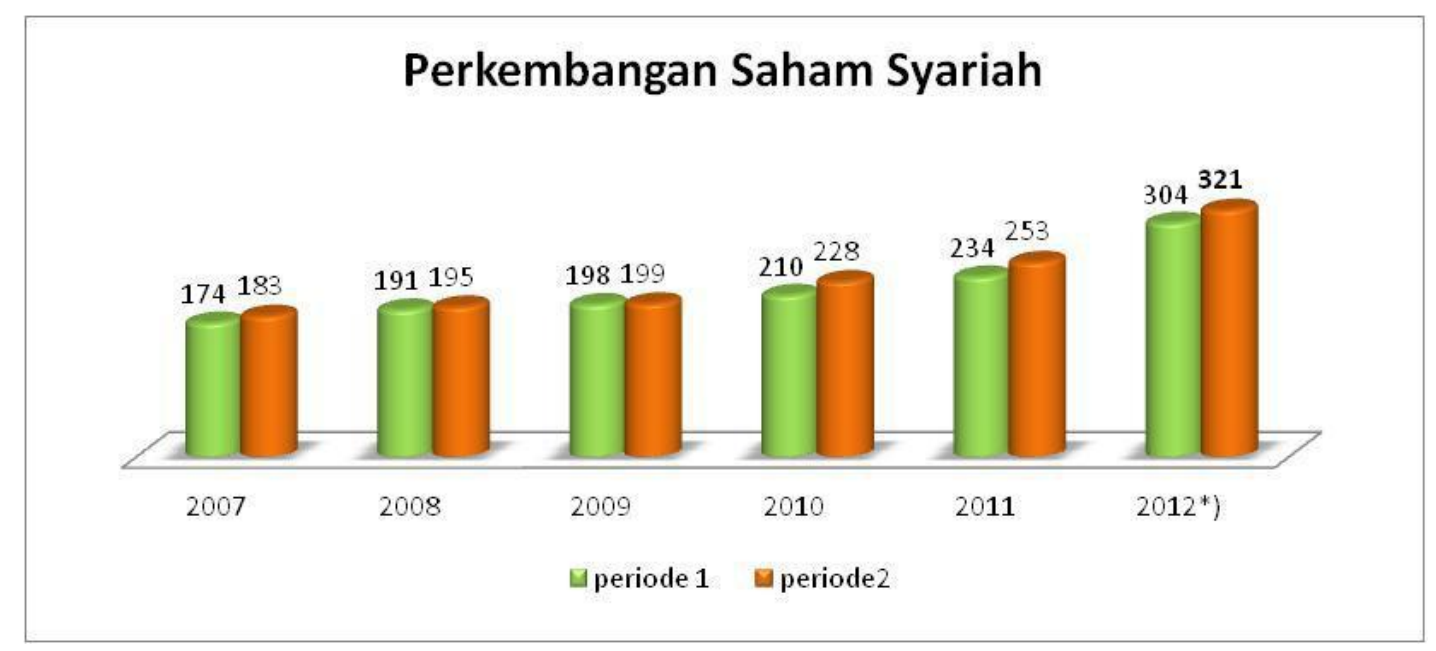

Sumber: Badan Pengawas Pasar Modal dan Lembaga Keuangan, 2013.

\section{Gambar 1. Perkembangan Saham Syariah di BEI Tahun 2007-2012}

*) per Maret 2013, DES yang berlaku adalah DES periode II tahun 2012 yang berjumlah 321 saham. Dari 321 saham tersebut, 317 saham diperoleh dari hasil penelaahan DES periodik per tanggal 22 November 2012 dan 4 saham diperoleh dari hasil penelaahan DES insidentil bersamaan dengan efektifnya pernyataan pendaftaran Emiten yang melakukan penawaran umum perdana.

Penetapan "total utang yang berbasis bunga tidak lebih dari $45 \%$ terhadap total asset" sebagai syarat utama untuk menjadi saham syariah berimplikasi secara langsung terhadap kekuatan pendanaan suatu perusahaan. Adapun kekuatan pendanaan di perusahaan memiliki peranan yang signifikan dalam analisis 
leverage keuangan. Oleh karena itu, pemilihan sumber dana yang baik dan tepat yang berasal dari dalam maupun dari luar perusahaan sangat mempengaruhi nilai perusahaan. Keputusan pendanaan ini berperan penting dalam dunia usaha saat ini. Penentuan pilihan pembiayaan perusahaan sangat tergantung pada kategori perusahaan atau industrinya. Sumber dana internal dapat berasal dari laba ditahan dan depresiasi. Sementara itu sumber dana eksternal dapat berasal dari kreditur pemenuhan dana yang merupakan utang bagi perusahaan. ${ }^{4}$

Proporsi penggunaan utang jangka panjang dan modal sendiri dalam memenuhi kebutuhan dana perusahaan selanjutnya disebut struktur modal. Nilai struktur modal tersebut dapat dihitung dengan menggunakan rasio Debt to Equity Ratio (DER) yang input variabelnya diperoleh dari laporan keuangan perusahaan.

Salah satu usaha yang dilakukan oleh perusahaan agar dapat bertumbuh dan berdaya saing adalah melalui pendanaan. Banyaknya perusahaan dalam industri, serta kondisi perekonomian saat ini telah menciptakan suatu persaingan yang ketat antar perusahaan di dalam industri yang sama. Persaingan dalam industri membuat setiap perusahaan semakin meningkatkan kinerja keuangan (tercermin dalam variabel fundamental perusahaan) agar tujuannya dapat tetap tercapai.

Struktur modal memiliki hubungan positif dan signifikan dengan kinerja perusahaan dalam memenangkan persaingan di industri yang sama. Dengan demikian dapat dikatakan bahwa sebuah perusahaan yang ingin memenangkan persaingan di industrinya seharusnya menentukan keputusan struktur modal dengan tepat dan baik.

Berdasarkan uraian di atas, dapat disimpulkan bahwa penelitian dengan fokus utama melihat pengaruh harga saham syariah sebagai apresiasi pelaku pasar atas nilai perusahaan terhadap struktur modal (DER), merupakan hal yang penting dan mendesak untuk dilakukan. Namun di sisi lain, struktur modal yang baik adalah struktur modal yang berkorelasi positif dengan rasio-rasio akuntansi/ keuangan yang bersifat fundamental (struktur aktiva, profitabilitas, financing deficit, market to book ratio, dan ukuran perusahaan).

Saham syariah yang menjadi objek penelitian adalah saham-saham emiten/ perusahaan publik yang selalu terdaftar di Jakarta Islamic Index dari tahun 2012 
sampai dengan 2014. Ketersediaan laporan keuangan emiten saham syariah yang dapat diakses oleh masyarakat umum pada periode yang sama merupakan batasan kedua dalam penelitian ini.

Berdasarkan uraian di atas maka dapat diajukan pertanyaan penelitian sebagai berikut:

1. Bagaimana faktor-faktor fundamental perusahaan (struktur aktiva, Market to Book Ratio, profitabilitas, ukuran perusahaan, pertumbuhan penjualan dan financing deficit) mempengaruhi Debt to Equity Ratio perusahaan yang tercatat di Daftar Efek Syariah (DES)?

2. Bagaimana Harga Saham Syariah mempengaruhi Debt to Equity Ratio perusahaan yang tercatat di DES?

3. Bagaimana faktor-faktor fundamental perusahaan dan Harga Saham Syariah mempengaruhi Debt to Equity Ratio perusahaan pada perusahaan yang tercatat di DES?

Hasil penelitian ini diharapkan dapat memberikan sumbangan ilmiah, berupa penjelasan mengenai struktur modal pada perusahaan-perusahaan di Indonesia yang tercatat dalam Daftar Efek Syariah di BEI. Hasil penelitian juga dapat dijadikan referensi bagi penelitian selanjutnya yaitu untuk menambah wawasan, pengetahuan, dan dapat berguna bagi pengembangan ilmu ekonomi dan bisnis Islam khususnya bidang kajian manajemen keuangan.

\section{B. Kerangka Pemikiran Konseptual Penelitian}

Penelitian ini diawali dengan pemilihan perusahaan-perusahaan yang tersebar pada berbagai sektor yang lolos kategori saham syariah dan selalu tercatat di JII dari tahun 2012 sampai dengan 2014. Penelitian ini kemudian dilanjutkan dengan pengumpulan data sekunder berupa laporan keuangan tahunan emiten yang terdiri dari neraca, laporan laba/rugi serta informasi mengenai harga saham syariah pada penutupan bursa tahun-tahun tersebut. Berdasarkan data harga saham syariah dan laporan keuangan tersebut, maka dilakukan analisis atas struktur modal perusahaan dan analisis kinerja keuangan perusahaan dengan menggunakan pendekatan deskriptif. 
Pada dasarnya penelitian ini berfokus pada hasil analisis faktor internal (karakteristik perusahaan) dalam menentukan variabel independen penelitian yakni berupa Market to Book Ratio, deficit financing (Def), size of firm, profitabilitas (ROA), tangible asset serta faktor harga saham syariah sebagai faktor eksternal. Adanya research gap yaitu inkonsistensi dari hasil beberapa penelitian terdahulu terhadap pengaruh fundamental perusahaan pada struktur modal serta minimnya penelitian yang menganalisis pengaruh harga saham syariah, yang akhirnya memotivasi tim peneliti untuk meneliti kedua faktor tersebut dimana fokus objek penelitian adalah perusahaan anggota Daftar Efek Syariah yang tercatat di JII. Kerangka pemikiran konseptual penelitian disajikan pada Gambar 2.

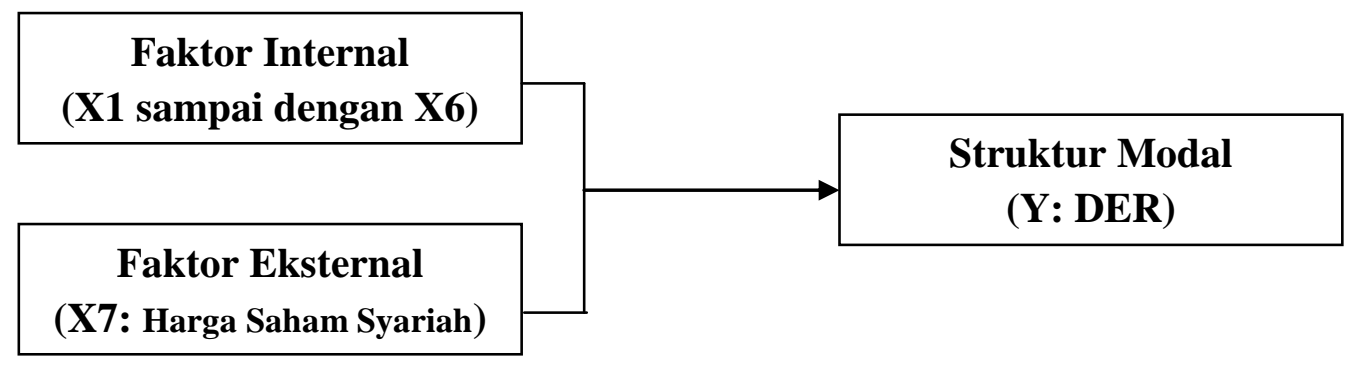

Gambar 2. Kerangka Berpikir

\section{Metode Penelitian}

\section{Tempat dan Waktu Penelitian}

Penelitian dilakukan di Bursa Efek Indonesia (BEI) dengan mengambil data berupa laporan keuangan perusahaan-perusahaan di berbagai sektor yang lolos kategori syariah dan tercatat di BEI yang diperoleh secara elektronis melalui situs resmi BEI yaitu www.idx.co.id, dan situs resmi perusahaan-perusahaan yang menjadi objek penelitian. Pengumpulan data dilaksanakan selama dua minggu, yaitu pada minggu ketiga dan minggu keempat bulan Mei 2017.

\section{Pendekatan Penelitian}

Penelitian ini merupakan penelitian kuantitatif yang mendeskripsikan fakta secara stastistik dan menunjukkan hubungan antara fakta dengan model matematis. Penelitian ini dilakukan dengan dua pendekatan yaitu secara deskriptif dan pendekatan kuantitatif yang memodelkan fenomena melalui model ekonometrika. Pendekatan deskriptif akan menggambarkan mengenai kebijakan struktur modal yang dianut perusahaan anggota 
Daftar Efek Syariah yang tercatat di BEI serta kinerja keuangan yang dicapai oleh masing-masing perusahaan tersebut. Sementara itu, pendekatan ekonometrika dilakukan dengan mengetahui hubungan antara kebijakan struktur modal yang dianut perusahaan dengan faktor-faktor fundamental perusahaan dan harga saham syariah.

\section{Jenis dan Sumber Data}

Data yang dikumpulkan dalam penelitian ini adalah data sekunder, baik yang bersifat kuantitatif maupun kualitatif, yaitu berupa laporan keuangan dan literatur-literatur pendukung lainnya. Data diperoleh dari BEI dan Otoritas Jasa Keuangan (OJK). Data-data sekunder yang dikumpulkan adalah sebagai berikut:

Tabel 1. Data yang Diperlukan dan Sumbernya

\begin{tabular}{|l|l|l|}
\hline No. & Data yang Diperlukan & Sumber \\
\hline 1 & Laporan keuangan tahunan: & Situs resmi BEI (www.idx.co.id) \\
& $-\quad$ Total asset & dan situs resmi perusahaan masing- \\
& $-\quad$ Utang jangka panjang & masing Emiten yang selalu tercatat \\
& $-\quad$ Total utang & 2014) di BEI melalui Jakarta \\
& $-\quad$ Total ekuitas & Islamic Index \\
& $-\quad$ Laba bersih setelah pajak & \\
& $-\quad$ Laba bersih per saham & - BEI \\
\hline 2 & Data pasar modal & Laporan Tahunan setiap \\
& $-\quad$ Harga saham & Emiten \\
\hline
\end{tabular}

\section{Definisi Operasional Variabel}

Adapun variabel penelitian dan definisi operasional variabel-variabel tersebut dapat dilihat pada tabel 2 berikut ini.

Tabel 2. Definisi Operasional Variabel

\begin{tabular}{|l|l|l|}
\hline Variabel Internal & Definisi Operasional & Skala \\
\hline $\begin{array}{l}\text { Faktor } \\
\text { (Fundamental) }\end{array}$ & $\begin{array}{l}\text { Mengukur kekurangan dana untuk } \\
\text { ekspansi perusahaan setelah ditopang } \\
\text { oleh dana dari dalam perusahaan (internal } \\
\text { financing). }\end{array}$ & Rasio \\
\hline $\begin{array}{l}\text { Financing Defisit } \\
\text { Xengukur seberapa besar porsi Nilai }\end{array}$ & Rasio \\
\hline $\begin{array}{l}\text { Tangible Asset } \\
(\mathrm{X} 2)\end{array}$ & $\begin{array}{l}\text { Mengukur } \text { besar nilai aset perusahaan } \\
\text { Size of Firm }(\mathrm{X} 3)\end{array}$ & Rasio \\
\hline Return on Asset & Mengukur seberapa besar laba operasi & Rasio \\
\hline
\end{tabular}




\begin{tabular}{|l|l|l|}
\hline (X4) & $\begin{array}{l}\text { (EBIT) yang dapat dicapai dari semua } \\
\text { aset perusahaan yang dioperasikan }\end{array}$ & \\
\hline $\begin{array}{l}\text { Sales Growth } \\
\text { (X5) }\end{array}$ & $\begin{array}{l}\text { Mengukur seberapa besar pertumbuhan } \\
\text { penjualan perusahaan }\end{array}$ & Rasio \\
\hline $\begin{array}{l}\text { Market to Book Value } \\
\text { (X6) }\end{array}$ & $\begin{array}{l}\text { Mengukur seberapa besar pasar } \\
\text { menghargai nilai buku per lembar saham } \\
\text { dibandingkan dengan nilai buku per } \\
\text { saham }\end{array}$ & Rasio \\
\hline Faktor Eksternal & $\begin{array}{l}\text { Mencerminkan apresiasi pelaku pasar } \\
\text { modal terhadap nilai perusahaan }\end{array}$ & Rasio \\
\hline Harga Saham Syariah & & \\
\hline Struktur Modal & $\begin{array}{l}\text { Menggambarkan seberapa besar proporsi } \\
\text { hutang jangka penjang terhadap modal } \\
\text { sendiri }\end{array}$ & Rasio \\
\hline Debt to Equity Ratio \\
(Y)
\end{tabular}

\section{Metode Pengolahan dan Analisis Data}

Seluruh estimasi dilakukan dengan program E-views dimana terdapat tiga model yang akan digunakan, yaitu:

a. Model regresi untuk menguji pengaruh faktor-faktor internal (fundamental) perusahaan terhadap Debt to Equity Ratio (DER) digunakan:

Model 1: $D E R_{\text {it }}=\alpha+\beta_{1} F_{A T A_{i t}}+\beta_{2} \mathrm{MTB}_{\text {it }}+\beta_{3} \operatorname{Size}_{i t}+\beta_{4} R O A_{\text {it }}+\beta_{5} S G_{\text {it }}$ $+\beta_{6} D e f_{\text {it }}+\varepsilon_{\mathrm{it}}$

b. Model regresi untuk menguji pengaruh faktor harga saham terhadap DER digunakan:

Model 2: $\boldsymbol{D E} \boldsymbol{R}_{\mathrm{it}}=\alpha+\beta H S_{\mathrm{it}}+\varepsilon_{\mathrm{it}}$

c. Model regresi untuk menguji pengaruh rasio-rasio keuangan fundamental dan harga saham terhadap DER menggunakan model sebagai berikut:

Model 3: $D E R_{\text {it }}=\alpha+\beta_{1} F_{A T A}+\beta_{2} \mathrm{MTB}_{\mathrm{it}}+\beta_{3} \mathrm{Size}_{\mathrm{it}}+\boldsymbol{\beta}_{4} R O A_{\mathrm{it}}+\beta_{5} S G_{\mathrm{it}}+$

$$
\beta_{6} D e f_{\mathrm{it}}+\beta_{7} H S_{\mathrm{it}}+\varepsilon_{\mathrm{it}}
$$

Keterangan:

$D E R_{\text {it }} \quad$ : Debt to Equity Ratio perusahaan i pada tahun $\mathrm{t}$

$H S_{\text {it }} \quad$ : Harga saham sebagi proksi dari nilai perusahaan i tahun $\mathrm{t}$

FATA $\quad$ : Fixed asset to total asset ratio perusahaan i pada tahun $\mathrm{t}$ 
$M_{\text {it }} \quad$ : Market to book ratio atau perbandingan Price Market dengan Book Value saham perusahaan i pada tahun $\mathrm{t}$

Size $_{\mathrm{it}} \quad$ : Size of firm yang diukur dengan logaritma natural Aset perusahaan i pada tahun $\mathrm{t}$

$R_{\text {RA }} \quad$ : Return on assets atau produktivitas Total Asset yang dicerminkan oleh Earning Before Interest and Taxes (EBIT) perusahaan i pada tahun $\mathrm{t}$

$S G_{\text {it }} \quad:$ Sales Growth perusahaan i pada tahun $\mathrm{t}$

Def $_{\text {it }} \quad$ : Financing Deficit atau selisih antara perubahan total asset dengan perubahan Retained Earning perusahaan i pada tahun t

$\alpha, \beta, \gamma, \delta:$ koefisien regresi

$\varepsilon_{\text {it }} \quad:$ error term

\section{Hasil Penelitian dan Pembahasan}

Data panel dapat dianalisis dengan menggunakan tiga macam pendekatan model yaitu: pooled least square, fixed effects model, dan random effects model. Penentuan model yang paling tepat untuk mengestimasi parameter regresi data panel dapat diringkas seperti pada Gambar 3.

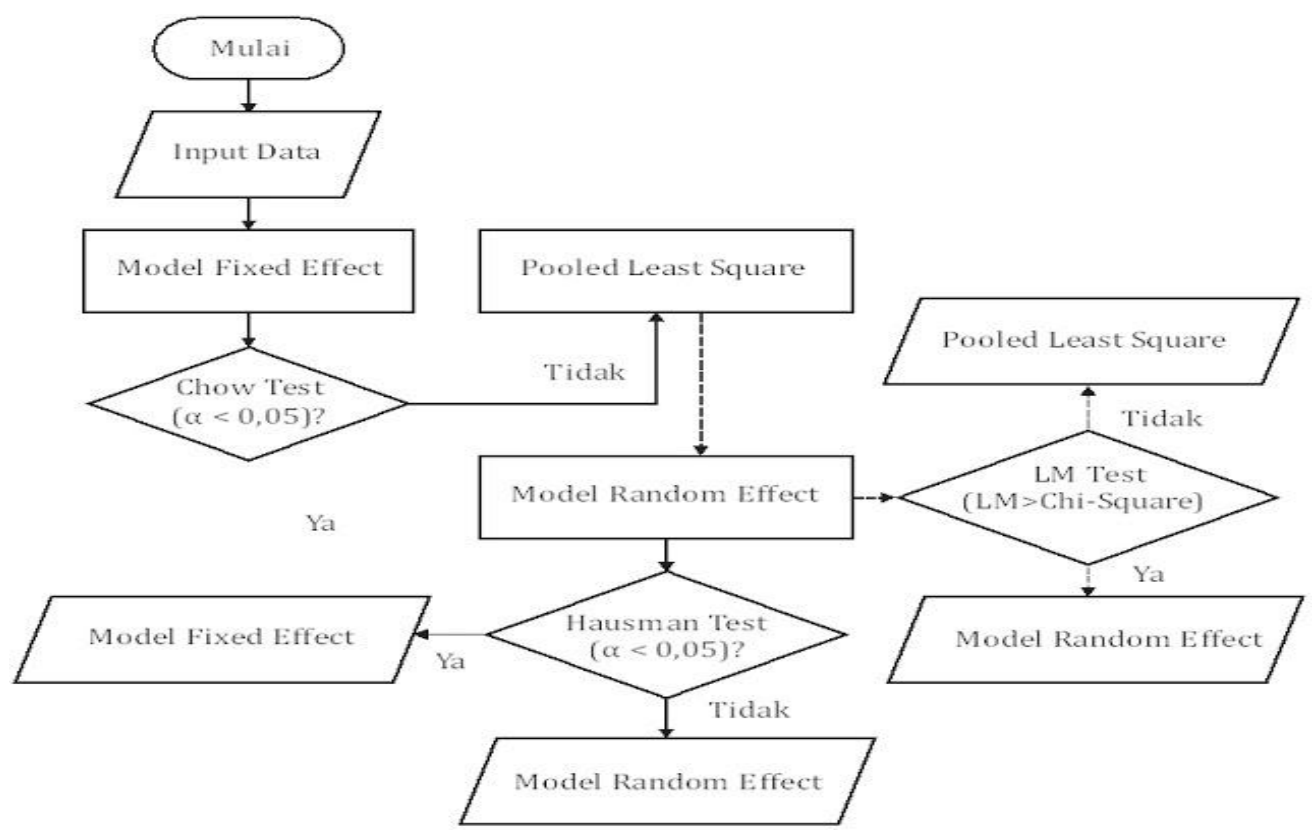

Gambar 3. Langkah-Langkah dalam Analisis Regresi Data Panel

\section{Statistik Deskriptif}

Berdasarkan data sampel perusahaan yang diperoleh dari laporan keuangan masing-masing perusahaan yang diteliti dari tahun 2012 sampai dengan 
tahun 2014 diperoleh deskripsi mengenai variabel-variabel yang digunakan pada penelitian ini. Statistik deskriptif variabel DER, FATA, MTB, Size, ROA, SG, DEF dan HS dapat dilihat pada Tabel 3. di bawah ini :

Tabel 3. Statistik Deskriptif Variabel-variabel Penelitian

\begin{tabular}{|l|l|l|l|l|}
\hline Variabel & N & Minimum & Maksimum & Mean \\
\hline & & & & \\
DER & 54 & 0.020000 & 1.216000 & 0.313093 \\
FATA & 54 & 0.056000 & 0.692000 & 0.321519 \\
MTB & 54 & 1.440000 & 46.63000 & 5.734074 \\
Size & 54 & 29.65300 & 33.09500 & 30.89331 \\
ROA & 54 & 3.570000 & 71.51000 & 15.56741 \\
SG & 54 & -0.108000 & 0.771000 & 0.139778 \\
DEF & 54 & -1734741000000 & 20933000000000 & 3446313175981.31 \\
HS & 54 & 430.0000 & 41550.00 & 10752.22 \\
\hline
\end{tabular}

Sumber: Data sekunder yang diolah

\section{Pemilihan Model Regresi}

Pooled Least Square (PLS) hanya akan diterapkan jika regresi Model Efek Tetap (MET) dan Model Efek Random (MER) terbukti tidak sesuai dengan datadata pada penelitian ini. Prioritas dalam model regresi dalam penelitian ini adalah:

- MET; Hausman test untuk membandingkan dengan MER.

- MER; jika MER lebih sesuai daripada MET, LM test untuk membandingkan dengan PLS.

- Pooled Least Square; Jika MET lebih sesuai daripada MER, Chow test untuk membandingkan antara MET dengan PLS

Tahap pemilihan metode/ model regresi linear yang paling tepat untuk tiga model penelitian membuktikan bahwa Pooled Least Square (PLS) adalah metode yang lebih baik daripada Model Efek Tetap dan Model Efek Random. Berikut ini adalah rekapitulasi pemilihan model regresi dan variabel-variabel yang berpengaruh terhadap struktur modal menurut model regresi terpilih tersebut. 
Tabel 4. Rekapitulasi Pemilihan Model Regresi

\begin{tabular}{|l|l|l|l|}
\hline & Model 1 & Model 2 & Model 3 \\
\hline Model paling sesuai & $\begin{array}{l}\text { Pooled Least } \\
\text { Square }\end{array}$ & $\begin{array}{l}\text { Pooled Least } \\
\text { Square }\end{array}$ & $\begin{array}{l}\text { Pooled Least } \\
\text { Square }\end{array}$ \\
\hline $\begin{array}{l}\text { Variabel independen yang } \\
\text { berpengaruh dengan } \boldsymbol{\alpha}=\mathbf{5 \%}\end{array}$ & $\begin{array}{l}\text { FATA, ROA dan } \\
\text { SG HS }\end{array}$ & $\begin{array}{l}\text { FATA, SG dan } \\
\text { HS }\end{array}$ \\
\hline $\begin{array}{l}\text { Variabel independen yang } \\
\text { berpengaruh dengan } \boldsymbol{\alpha}=\mathbf{1 0} \%\end{array}$ & $\begin{array}{l}\text { FATA, MTB, } \\
\text { ROA dan SG }\end{array}$ & FSTA, SG dan \\
R-squared & 0,391914 & 0,269033 & 0,446211 \\
\hline
\end{tabular}

\section{Model 1 (Pengaruh Faktor-faktor Internal terhadap Struktur Modal)}

Pooled Least Square (PLS) merupakan pendekatan model data panel yang paling sederhana karena hanya dengan mengkombinasikan data time series dan cross section dalam bentuk pool, dan menggunakan teknik kuadrat terkecil atau least square untuk mengestimasi koefisiennya. Pada model ini tidak diperhatikan dimensi waktu maupun individu, sehingga diasumsikan bahwa perilaku individu tidak berbeda dalam berbagai kurun waktu.

\section{Tabel 5. Output Regresi Pooled Least Square untuk Model 1}

Dependent Variable: DER

Method: Panel Least Squares

Date: 05/30/17 Time: 00:32

Sample: 20122014

Periods included: 3

Cross-sections included: 18

Total panel (balanced) observations: 54

\begin{tabular}{lllll}
\hline \hline Variable & Coefficient & Std. Error & t-Statistic & Prob. \\
\hline \hline C & -0.985411 & 1.703185 & -0.578570 & 0.5656 \\
FATA & -0.490943 & 0.222343 & -2.208043 & 0.0322 \\
MTB & 0.011367 & 0.006491 & 1.751287 & 0.0864 \\
SIZE & 0.047693 & 0.056548 & 0.843410 & 0.4033 \\
ROA & -0.011826 & 0.005479 & -2.158536 & 0.0360 \\
SG & 0.540055 & 0.176408 & 3.061403 & 0.0036 \\
DEF & $7.66 \mathrm{E}-15$ & $1.03 \mathrm{E}-14$ & 0.741422 & 0.4621 \\
\hline \hline R-squared & 0.460754 & Mean dependent var & 0.313093 \\
Adjusted R-squared & 0.391914 & S.D. dependent var & 0.273515 \\
S.E. of regression & 0.213287 & \multicolumn{2}{c}{ Akaike info criterion } & -0.131933
\end{tabular}




\begin{tabular}{llll} 
Sum squared resid & 2.138093 & Schwarz criterion & 0.125898 \\
Log likelihood & 10.56220 & Hannan-Quinn criter. & -0.032498 \\
F-statistic & 6.693123 & Durbin-Watson stat & 0.770633 \\
Prob(F-statistic) & 0.000036 & & \\
\hline \hline
\end{tabular}

Hasil pengolahan data menunjukkan bahwa variabel-variabel fundamental (Model 1) yang berpengaruh terhadap struktur modal perusahaan-perusahaan yang diteliti adalah variabel FATA, ROA dan SG untuk $\alpha=5 \%$ dan variabel FATA, MTB, ROA dan SG untuk $\alpha=10 \%$. Model 1 dapat menjelaskan perubahan DER (struktur modal) sebesar 39,19\%. FATA adalah variabel struktur aktiva (tangible asset) yang mengukur seberapa besar porsi nilai Fixed Asset dalam aset perusahaan. ROA (Return on Asset) adalah variabel yang mengukur seberapa besar laba operasi (EBIT) yang dapat dicapai dari semua aset perusahaan yang dioperasikan. Sedangkan SG adalah variabel yang mengukur pertumbuhan penjualan/ penerimaan suatu periode jika dibandingkan dengan penjualan/ penerimaan periode sebelumnya.

\section{Model 2 (Pengaruh Harga Saham terhadap Struktur Modal)}

Hasil output regresi terpilih (pooled least square) untuk Model 2 dalam penelitian ini dapat dilihat pada Tabel 6.

\section{Tabel 6. Output Regresi Pooled Least Square untuk Model 2}

Dependent Variable: DER

\begin{tabular}{lllll}
\hline \hline Variable & Coefficient & Std. Error & t-Statistic & Prob. \\
\hline \hline C & 0.470470 & 0.048231 & 9.754435 & 0.0000 \\
HS & $-1.46 \mathrm{E}-05$ & $3.35 \mathrm{E}-06$ & -4.374769 & 0.0001 \\
\hline \hline R-squared & 0.269033 & Mean dependent var & 0.313093 \\
Adjusted R-squared & 0.254976 & S.D. dependent var & 0.273515 \\
S.E. of regression & 0.236084 & Akaike info criterion & -0.012921 \\
Sum squared resid & 2.898263 & Schwarz criterion & 0.060745 \\
Log likelihood & 2.348879 & Hannan-Quinn criter. & 0.015489 \\
F-statistic & 19.13861 & Durbin-Watson stat & 0.374973 \\
Prob(F-statistic) & 0.000059 & & \\
\hline \hline
\end{tabular}

Model 2 penelitian yang mengkhususkan untuk meneliti pengaruh harga saham (HS) terhadap struktur modal juga menunjukkan hasil positif. Tiga metode regresi 
yang digunakan (MET, MER dan PLS) seluruhnya menghasilkan output bahwa harga saham syariah sangat berpengaruh signifikan terhadap kebijakan struktur modal perusahaan-perusahaan yang diteliti. Output analisis regresi dengan metode pooled least square memperlihatkan bahwa variabel HS sangat berpengaruh terhadap variabel DER, baik untuk level siginifikansi 5\% maupun untuk level siginifikansi $10 \%$. Variabel HS pada Model 2 dapat menjelaskan fenomena perubahan struktur modal sebesar $26,90 \%$.

\section{Model 3 (Pengaruh Faktor Internal dan Eksternal terhadap Struktur Modal)}

Hasil output regresi terpilih (pooled least square) untuk Model 3 dalam penelitian ini dapat dilihat pada Tabel 7.

\section{Tabel 7. Output Regresi Pooled Least Square untuk Model 3}

Dependent Variable: DER

\begin{tabular}{lllll}
\hline \hline Variable & Coefficient & Std. Error & t-Statistic & Prob. \\
\hline \hline C & -1.745251 & 1.656735 & -1.053428 & 0.2976 \\
FATA & -0.557867 & 0.214058 & -2.606148 & 0.0123 \\
MTB & 0.010121 & 0.006216 & 1.628103 & 0.1103 \\
SIZE & 0.075086 & 0.055190 & 1.360500 & 0.1803 \\
ROA & -0.006964 & 0.005617 & -1.239826 & 0.2213 \\
SG & 0.429722 & 0.174676 & 2.460113 & 0.0177 \\
DEF & $9.21 \mathrm{E}-16$ & $1.03 \mathrm{E}-14$ & 0.089814 & 0.9288 \\
HS & $-8.82 \mathrm{E}-06$ & $3.72 \mathrm{E}-06$ & -2.368148 & 0.0221 \\
& & & & 0.313093 \\
R-squared & 0.519353 & Mean dependent var & 0.273515 \\
Adjusted R-squared & 0.446211 & S.D. dependent var & -0.209934 \\
S.E. of regression & 0.203542 & Akaike info criterion & 0.084730 \\
Sum squared resid & 1.905752 & Schwarz criterion & -0.096294 \\
Log likelihood & 13.66822 & Hannan-Quinn criter. & 0.707813 \\
F-statistic & 7.100606 & Durbin-Watson stat & \\
Prob(F-statistic) & 0.000009 & & \\
\hline \hline
\end{tabular}

Model 3 adalah model penelitian untuk menganalisis pengaruh variabelvariabel internal perusahaan yang bersifat fundamental dan sekaligus harga saham sebagai variabel eksternal terhadap kebijakan struktur modal perusahaan yang terdaftar di Jakarta Islamic Index selama periode tahun 2012 sampai dengan 2014. Analisis regresi terhadap Model 3 memperlihatkan bahwa harga saham 
berpengaruh terhadap struktur modal. Dengan demikian faktor eksternal (harga saham) yang berada diluar kendali manajemen perusahaan memiliki andil dalam mengambil kebijakan struktur modal. Model 3 juga menghasilkan output analisis regresi yang menunjukkan bahwa variabel internal fundamental yang berpengaruh terhadap struktur modal adalah struktur aktiva (FATA) dan pertumbuhan penjualan/ penerimaan (SG). Model 3, yang merupakan gabungan variabelvariabel dalam Model 1 dan Model 2 ternyata memiliki $R$-squared yang lebih besar daripada kedua model tersebut. Model 3 memiliki $R$-squared sebesar 0,446211. Hal ini berarti bahwa faktor-faktor fundamental (rasio keuangan) perusahaan dan harga saham dapat menjelaskan dinamika perubahan struktur modal sebesar $44,62 \%$.

\section{Interpretasi Koefisien Variabel Independen}

Arah dan nilai pengaruh sebuah variabel bebas dapat dilihat dari koefisien variabel bebas tersebut. Berikut adalah rekapitulasi koefisien variabel-variabel independen yang berpengaruh terhadap struktur modal, baik dalam Model 1, Model 2 maupun Model 3.

Tabel 8. Koefisien Variabel Independen yang Berpengaruh terhadap Struktur Modal

\begin{tabular}{|l|l|l|l|l|l|}
\hline \multicolumn{2}{|l|}{ Model 1 (PLS) } & \multicolumn{2}{l|}{ Model 2 (PLS) } & \multicolumn{2}{l|}{ Model 3 (PLS) } \\
\hline Variabel bebas & Koefisien & Variabel bebas & Koefisien & Variabel bebas & koefisien \\
\hline FATA & $-0,490943$ & HS & $-1,46 \mathrm{E}-05$ & FATA & $-0,557867$ \\
\hline MTB* & 0,011367 & & & SG & 0,429722 \\
\hline ROA & $-0,011826$ & & & HS & $-8,82$ E-06 \\
\hline SG & 0,540055 & & & & \\
\hline
\end{tabular}

*signifikan pada tingkat $\alpha=10 \%$

Tabel 8. menunjukkan bahwa Model 1 memiliki dua variabel yang berpengaruh positif dan dua variabel yang berpengaruh negatif terhadap struktur modal. Struktur aktiva (FATA) dan Tingkat Pengembalian atas Aset (ROA) memiliki pengaruh negatif sebesar 0,490943 dan 0,011826. Hal ini berarti bahwa bobot pengaruh negatif FATA lebih besar daripada bobot pengaruh negatif ROA terhadap struktur modal perusahaan yang diteliti. Begitu juga halnya dengan variabel yang berpengaruh positif (MTB dan SG). Pengaruh positif pertumbuhan penjualan (SG) memiliki bobot yang lebih besar daripada pengaruh positif MTB 
(harga saham relatif terhadap nilai buku saham) terhadap struktur modal/ Debt to Equity Ratio.

Model 2 yang bertujuan untuk melihat pengaruh harga saham (sebagai satu-satunya variabel independen) terhadap DER, memiliki koefisien sebesar -1,46E-05. Dengan demikian diketahui bahwa harga saham (HS) berpengaruh negatif terhadap struktur modal dengan bobot sebesar 1,46E-05. Maka apabila terjadi peningkatan harga saham perusahaan, akan mempengaruhi manajemen perusahaan untuk menurunkan rasio struktur modal (DER-nya). Dengan kata lain, peningkatan harga saham di pasar modal mempengaruhi perusahaan untuk mengurangi proporsi utang jangka panjang terhadap ekuitas (modal sendiri).

Output Model 3 menunjukkan bahwa variabel FATA dan HS berpengaruh negatif terhadap struktur modal sebesar -0,557867 dan -8,82E-06. Pengaruh kedua variabel tersebut konsisten dengan kedua model penelitian sebelumnya. Dimana FATA pada Model 1 dan HS pada Model 2 juga bernilai negatif. Satu-satunya variabel fundamental yang berpengaruh positif terhadap struktr modal adalah variabel SG. Hal ini mengindikasikan bahwa peningkatan pertumbuhan penjualan/ Sales Growth (SG) mempengaruhi manajemen perusahaan untuk meningkatkan proporsi utang jangka panjangnya terhadap jumlah ekuitas/ modal sendiri.

\section{E. Kesimpulan}

Faktor-faktor fundamental perusahaan yang tercermin dalam rasio-rasio keuangan dan berpengaruh terhadap kebijakan penentuan proporsi struktur modal adalah rasio/ variabel FATA, MTB, ROA dan SG. Hasil ini diperoleh berdasarkan hasil analisis regresi terhadap Model 1. Adapun pengaruh Harga Saham Syariah juga cukup signifikan terhadap struktur modal (DER) ketika tim peneliti menganalisis pengaruh variabel HS sebagai variabel independen satu-satunya dalam Model 2.

Model 3 sebagai formula untuk melihat pengaruh faktor-faktor fundamental perusahaan (internal) dan Harga Saham Syariah (eksternal) terhadap struktur modal memberikan nilai $R$-square yang lebih besar jika dibandingkan dengan $R$ square Model 1 dan Model 2. Hal ini mengindikasikan bahwa Model 3 (faktor 
internal dan eksternal) dapat menjelaskan perubahan struktur modal lebih baik daripada Model 1 (faktor internal) dan Model 2 (faktor eksternal).

\section{Endnotes:}

${ }^{1}$ Bapepam-LK bekerja sama dengan Dewan Syariah Nasional MUI (DSN-MUI) dalam menetapkan persyaratan untuk menjadi anggota Daftar Efek Syariah.

${ }^{2}$ Badan Pengawas Pasar Modal dan Lembaga Keuangan, Bapepam-LK Factbook 2007 (Jakarta: Bapepam-LK, 2007), hlm. 5.

${ }^{3}$ Dewan Syariah Nasional, Himpunan Fatwa Dewan Syariah Nasional (Jakarta: DSNMUI, 2003), hlm. 272.

${ }^{4}$ M.S. Ramaratman dan R. Jayaraman, Impact of Financial Strength on Leverage: A Study with Special Reference to Select Companies in India (International Monthly Refereed Journal of Research in Management and Technology, 2013) hlm. 34.

\section{DAFTAR PUSTAKA}

BEI. 2012. IDX’s Fact Book 2011. Jakarta: Bursa Efek Indonesia.

BEI. 2013. IDX's Fact Book 2012. Jakarta: Bursa Efek Indonesia.

BEI. 2014. IDX’s Fact Book 2013. Jakarta: Bursa Efek Indonesia.

BEI. 2015. IDX's Fact Book 2014. Jakarta: Bursa Efek Indonesia.

Dewan Syariah Nasional. 2003. Himpunan Fatwa Dewan Syariah Nasional. Jakarta: Dewan Syariah Nasional.

Ramaratman, M. S., dan R. Jayaraman. 2013. Impact of Financial Strength on Leverage: A Study with Special Reference to Select Companies in India. International Montly Refereed Journal of Research in Management and Technology [Internet] [diunduh 2013 Juni 21]; 2: 34-38 Tersedia pada www.search.proquest.com.

Weston, J. F. dan E. F. Brigham. 1990. Essentials of Managerial Financial. Ninth Edititon. The Dryden Press. 